\title{
Germinability of Teliospores of Tilletia indica after Hot Water and Sodium Hypochlorite Treatments
}

\author{
J. L. Smilanick, USDA-ARS, 2021 South Peach Avenue, Fresno, CA 93727; W. Hershberger, USDA-ARS, \\ 45 Wiltshire Road, Kearneysville, WV 25430; and M. R. Bonde and S. E. Nester, USDA-ARS, Fort Detrick, \\ Frederick, MD 21702
}

\begin{abstract}
Smilanick, J. L., Hershberger, W., Bonde, M. R., and Nester, S. E. 1997. Germinability of teliospores of Tilletia indica after hot water and sodium hypochlorite treatments. Plant Dis. 81:932935.

Hot water and sodium hypochlorite $(\mathrm{NaOCl})$ were evaluated to eradicate teliospores of the Karnal bunt fungus, Tilletia indica, for the purpose of decontaminating grain storage and handling equipment. The germinability of free teliospores and teliospores within the sori of infected wheat was assessed. Temperatures of 25,60 , and $80^{\circ} \mathrm{C}, \mathrm{NaOCl}$ concentrations $(\mathrm{wt} / \mathrm{vol}$, $\mathrm{pH} 11.5$ ) of $0,0.53$, and $1.60 \%$, and immersion periods of $1,5,15$, and 30 min were evaluated. In other tests, the influence of $\mathrm{pH}$ on $\mathrm{NaOCl}$ potency and of a delay between treatment and water rinsing were evaluated. Immersion at $80^{\circ} \mathrm{C}$ in water alone or with $\mathrm{NaOCl}$ killed both free teliospores and those within the sori of infected seeds within $1 \mathrm{~min} . \mathrm{NaOCl}$ at $1.60 \%$ at $25^{\circ} \mathrm{C}$ killed teliospores suspended in water within $15 \mathrm{~min}$, but some teliospores inside sori survived $30 \mathrm{~min}$ of this treatment. $\mathrm{NaOCl}$ adjusted to $\mathrm{pH} 8$ before use was superior to $\mathrm{NaOCl}$ at $\mathrm{pH}$ 11.5. An application of $1.60 \% \mathrm{NaOCl}$ at $25^{\circ} \mathrm{C}$ for 5 min followed by a 10 -min delay before the seeds were rinsed in fresh water killed free teliospores but not all teliospores within sori. This treatment was more effective than the 5-min treatment alone but inferior to the 15-min treatment with $\mathrm{NaOCl}$ at a concentration of $1.60 \%$. Because teliospores within the sori of infected seeds are partially protected and much more resistant to $\mathrm{NaOCl}$, we recommend the removal and disposal of seeds from equipment before the treatments are applied. $\mathrm{NaOCl}$ radically altered the appearance of the teliospores, leaving a persistent visual indication that they had been treated, while hot water treatment alone did not. Therefore, it is beneficial to add $\mathrm{NaOCl}$ to hot water, although the improvement in the sporicidal efficacy was often small.
\end{abstract}

Karnal bunt of wheat, caused by Tilletia indica Mitra (syn. Neovossia indica (Mitra) Mundk.), a seed- and soilborne flower-infecting bunt of wheat, was first reported from northwest India in 1931 and has spread since that time and become the object of intensive quarantine efforts $(5,13)$. Contaminating teliospores can reside within the sori of Karnal bunt-infected wheat seeds or on the surfaces of healthy seeds, bins, combines, railcars, and elevators. Seeds infected with $T$. indica were found in the state of Arizona in the United States in March 1996 (17). This occurrence, the first report of Karnal bunt in the United States, elicited an effort by regulatory agencies to establish emergency measures to contain the distribution of teliospores on contaminated seeds, field equipment, and grainprocessing facilities.

Corresponding author: J. L. Smilanick E-mail: jsmilanick@aol.com

Accepted for publication 7 May 1997.

\section{Publication no. D-1997-0605-04R}

This article is in the public domain and not copyrightable. It may be freely reprinted with customary crediting of the source. The American Phytopathological Society, 1997.
A decontamination treatment should be fast, effective, inexpensive, and readily available. It should pose minimal hazards to workers and the environment, and it should leave a persistent indication that a treatment has been applied (e.g., bleaching of the teliospores) so that compliance with treatment protocols is evident. Because the unruptured periderm of the sori protects teliospores from many chemical treatments $(12,15)$, infected seeds should be included in efficacy tests of decontamination treatments. Among decontamination treatments issued by the U.S. Department of Agriculture's Animal Plant Health Inspection Service are (i) immersion in a $30 \%$ (vol/ vol) solution of laundry bleach $(5.25 \%$ [wt/vol] $\mathrm{NaOCl}$ ) for 15 min followed by a fresh water rinse; and (ii) hot water or steam applied with a point-of-contact temperature of $80^{\circ} \mathrm{C}$. The efficacy of these treatments has not been evaluated.

The temperatures required to kill teliospores under moist or dry conditions can be estimated from prior studies in which the objectives were to control teliospore germination in soil or seeds $(6,9,10,12)$. The moisture status of the teliospores at the time of treatment greatly influences the temperatures at which mortality occurs. In water or moist soil heated to 50 to $55^{\circ} \mathrm{C}$, mortality of $T$. indica teliospores occurs after about 0.5 to $5 \mathrm{~h}(6,9,10,12)$. Teliospores are much more resistant to heat under dry conditions. In dry air heated to $100,110,125$, or $140^{\circ} \mathrm{C}$, teliospores survived $88 \mathrm{~h}, 12 \mathrm{~h}, 1 \mathrm{~h}$, or $10 \mathrm{~min}$, respectively $(4,12)$. The susceptibility of teliospores to heat within unruptured sori is difficult to predict, because their moisture content during a moist or wet treatment would be increasing, thereby decreasing their sensitivity to heat.

$\mathrm{NaOCl}$ potency is improved by heating, increasing its concentration, and by decreasing solution $\mathrm{pH}$ before use $(2,8)$. Chastain (1) and Smilanick and coworkers (11) reported that heating the $\mathrm{NaOCl}$ accelerated the mortality of teliospores of Tilletia species. For example, teliospores of $T$. controversa were killed by an 18-min treatment with $0.25 \% \mathrm{NaOCl}$ at $23^{\circ} \mathrm{C}$, while at $50^{\circ} \mathrm{C}$, a treatment of only $3 \mathrm{~min}$ was required (11). Reducing the $\mathrm{pH}$ of $\mathrm{NaOCl}$ solutions increases the proportion of hypochlorous acid, the germicidal component of free hypochlorite (16), and improves $\mathrm{NaOCl}$ effectiveness for cereal seed disinfection (8). Smilanick and coworkers (12) reported that germination levels of teliospores of $T$. indica after immersion for 10 min in $0.25 \% \mathrm{NaOCl}$ at $\mathrm{pH} 11$ and $\mathrm{pH} 6$ were 22.9 and $0 \%$, respectively. However, hypochlorite solutions below $\mathrm{pH} 6$ or those heated at neutral $\mathrm{pH}$ can decompose to release chlorine gas, which is a safety hazard and also more corrosive to equipment (16).

The objective of this work was to determine the efficacy of hot water and $\mathrm{NaOCl}$, alone or in combination, to kill teliospores of $T$. indica suspended in water, on the surface of healthy seeds, or within the unruptured sori of infected seeds.

\section{MATERIALS AND METHODS}

Two-year-old $T$. indica-infected wheat seeds were obtained from a variety trial in a containment facility located in Ft. Detrick, MD. (All experiments were conducted there under permit). Infected seeds classified 1 to 2 (point infections) by the definition of Warham, Mujeeb-Kazi, and Rosas (14) were selected from seeds threshed by hand from infected spikes. Only seeds with unruptured sori, with the periderm intact, were used in the experiments with infected seeds. The sori of seeds of this infection class are more difficult to rupture by mechanical pressure and often 
remain intact after passing through commercial combines.

Free teliospores were prepared by gently crushing severely infected seeds, classified 3 to 5 (14), with a mortar and pestle and passing the teliospores through a $60-\mu \mathrm{m}$ pore-size sieve to remove debris. For each treatment, a suspension of about 1,000 teliospores in $200 \mu \mathrm{l}$ of water and three infected seeds with unruptured sori were immersed in $40 \mathrm{ml}$ of the test solutions in capped, presterilized, 50-ml-capacity conical centrifuge tubes. $\mathrm{NaOCl}$ solutions of $0,0.53$, or $1.60 \%$ were prepared immediately before use and preheated to the exposure temperature. The tubes were suspended in a water bath at 25,60 , or $80^{\circ} \mathrm{C}$ and incubated for 1 , 5,15 , or $30 \mathrm{~min}$. The temperature in the solutions was monitored with 1-mm-diameter type T probes (Gaffney Engineering, Gainesville, FL) attached to a thermocouple thermometer (model HH11, Omega Engineering, Stamford, CT). Free hypochlorite concentrations in treatment solutions were measured spectrophotometrically at $528 \mathrm{~nm}$ by using $N, N$-diethyl- $p$ phenylenediamine (16).

To terminate each treatment, free teliospore solutions and infected seeds with intact sori were placed on an 8 - $\mu$ m-poresize filter and rinsed three times with 5-ml volumes of 20 to $25^{\circ} \mathrm{C}$ sterile water. The infected seeds were removed from the filter; and the filter was removed, inverted, and applied to and removed from the surface of a petri dish containing $2 \%$ (wt/vol) agar amended with $100 \mathrm{mg}$ each of ampicillin and streptomycin sulfate per liter to minimize contamination. The three infected seeds with intact sori retained from each treatment were transferred to a sterile petri dish, and the sori were excised with a scalpel and crushed in a small volume of sterile water. This teliospore-containing solution was poured through a second filter apparatus, and a 5-ml volume of sterile water was applied to rinse and disperse the teliospores on the filter. The spores were transferred to an agar plate as previously described. Each agar plate had about 300 to 500 teliospores on the agar surface.

The agar plates were incubated under optimal conditions for germination $\left(15^{\circ} \mathrm{C}, 12\right.$-h light-dark cycle), and all were examined after 34 to 38 days to determine the percentages of germinated teliospores. In each experiment, 300 teliospores were examined from each treatment. Each experiment was conducted three times. Teliospores were classified as germinated if any germination products, such as promycelia or sporidia, were present. For statistical analysis, germination percentages were arcsine transformed before an analysis of variance was applied followed by Duncan's new multiple range test $(P \leq 0.05)$ or orthogonal comparisons to separate effects. To compare some treatments, the time at which $99 \%$ teliospore mortality occurred was calculated by using Finney's probit analysis (3).

\section{RESULTS}

The temperature of the water and the $\mathrm{NaOCl}$ solutions did not change during the treatments. Solutions of $1.60 \% \mathrm{NaOCl}$ at $\mathrm{pH} 11.5$ at 25,60 , and $80^{\circ} \mathrm{C}$ were stable, while those at $\mathrm{pH} 8$ were stable only at $25^{\circ} \mathrm{C}$ and quickly decomposed at $60^{\circ} \mathrm{C}$. Therefore, $\mathrm{NaOCl}$ solutions adjusted to $\mathrm{pH}$ 8 were evaluated only at $25^{\circ} \mathrm{C}$. The free hypochlorite concentration did not change during most tests; the greatest loss, a decrease of $20 \%$, occurred during treatment

Table 1. Teliospore germination 34 to 38 days after treatment with water or $\mathrm{NaOCl}$ for 1 to $30 \mathrm{~min}$ at 25,60 , or $80^{\circ} \mathrm{C}$

\begin{tabular}{|c|c|c|c|c|}
\hline \multirow{2}{*}{$\begin{array}{l}\text { Temperature } \\
\left({ }^{\circ} \mathrm{C}\right)\end{array}$} & \multirow{2}{*}{$\begin{array}{c}\mathrm{NaOCl} \\
(\%)\end{array}$} & \multirow{2}{*}{$\underset{\text { (min) }}{\text { Exposure }}$} & \multicolumn{2}{|c|}{ Teliospore germination $(\% \pm \mathrm{SD})^{\mathrm{y}}$} \\
\hline & & & Free & From sori \\
\hline 25 & $\begin{array}{l}0 \\
0 \\
0 \\
0 \\
0.53 \\
0.53 \\
0.53 \\
0.53 \\
1.60 \\
1.60 \\
1.60 \\
1.60\end{array}$ & $\begin{array}{r}1 \\
5 \\
15 \\
30 \\
1 \\
5 \\
15 \\
30 \\
1 \\
5 \\
15 \\
30\end{array}$ & $\begin{array}{l}28.0 \pm 10.4 \\
33.8 \pm 9.1 \\
38.5 \pm 15.3 \\
38.5 \pm 9.5 \\
16.6 \pm 9.5 \\
13.1 \pm 14.2 \\
1.3 \pm 1.3 \\
0.3 \pm 0.3 \\
9.1 \pm 1.9 \\
0.8 \pm 0.6 \\
0.0 \\
0.0\end{array}$ & $\begin{array}{c}39.7 \pm 22.6 \\
69.6 \pm 6.8 \\
47.7 \pm 13.0 \\
36.0 \pm 19.0 \\
50.5 \pm 15.6 \\
33.8 \pm 30.4 \\
27.5 \pm 20.4 \\
29.2 \pm 24.4 \\
37.3 \pm 30.6 \\
41.4 \pm 12.6 \\
10.8 \pm 4.4 \\
7.6 \pm 5.4\end{array}$ \\
\hline 60 & $\begin{array}{l}0 \\
0 \\
0 \\
0 \\
0.53 \\
0.53 \\
0.53 \\
0.53 \\
1.60 \\
1.60 \\
1.60 \\
1.60\end{array}$ & $\begin{array}{r}1 \\
5 \\
15 \\
30 \\
1 \\
5 \\
15 \\
30 \\
1 \\
5 \\
15 \\
30\end{array}$ & $\begin{array}{l}4.2 \pm 1.7 \\
1.7 \pm 0.3 \\
0.3 \pm 0.3 \\
0.1 \pm 0.2^{\mathrm{z}} \\
0.4 \pm 0.5 \\
0.2 \pm 0.2^{\mathrm{z}} \\
0.0 \\
0.0 \\
0.1 \pm 0.2^{\mathrm{z}} \\
0.1 \pm 0.2^{\mathrm{z}} \\
0.0 \\
0.0\end{array}$ & $\begin{array}{c}21.3 \pm 15.3 \\
15.0 \pm 6.3 \\
0.1 \pm 0.2^{\mathrm{z}} \\
0.0 \\
32.1 \pm 28.3 \\
8.3 \pm 13.4 \\
1.3 \pm 2.3 \\
0.0 \\
55.7 \pm 11.2 \\
6.9 \pm 9.9 \\
0.0 \\
0.0\end{array}$ \\
\hline 80 & $\begin{array}{l}0 \\
0 \\
0 \\
0 \\
0.53 \\
0.53 \\
0.53 \\
0.53 \\
1.60 \\
1.60 \\
1.60 \\
1.60 \\
\end{array}$ & $\begin{array}{r}1 \\
5 \\
15 \\
30 \\
1 \\
5 \\
15 \\
30 \\
1 \\
5 \\
15 \\
30 \\
\end{array}$ & $\begin{array}{l}0.0 \\
0.0 \\
0.0 \\
0.0 \\
0.0 \\
0.0 \\
0.0 \\
0.0 \\
0.0 \\
0.0 \\
0.0 \\
0.0\end{array}$ & $\begin{array}{l}0.0 \\
0.1 \pm 0.2^{\mathrm{z}} \\
0.0 \\
0.0 \\
0.0 \\
0.1 \pm 0.2^{\mathrm{z}} \\
0.0 \\
0.0 \\
0.0 \\
0.0 \\
0.0 \\
0.0\end{array}$ \\
\hline
\end{tabular}

${ }^{y}$ Each value is the mean of three experiments in each of which 300 teliospores were examined.

${ }^{\mathrm{z}}$ One teliospore germinated on one agar plate in one experiment.

Table 2. Teliospore germination after immersion in $\mathrm{NaOCl}, \mathrm{pH} 8$ or 11.5 , for $5 \mathrm{~min}$ and a rinse in fresh water after a delay of 10 min or immersion in $\mathrm{NaOCl}(1.60 \%), \mathrm{pH} 11.5$, for 5 or $15 \mathrm{~min}$ followed by an immediate rinse in fresh water

\begin{tabular}{lcccccc}
\hline & & & & \multicolumn{2}{c}{$\begin{array}{c}\text { Teliospore germination } \\
(\% \pm \text { SD) }\end{array}$} \\
\cline { 5 - 7 } $\begin{array}{l}\text { NaOCl } \\
(\%)\end{array}$ & $\mathbf{p H}$ & $\begin{array}{c}\text { Temperature } \\
\left({ }^{\circ} \mathbf{C}\right)\end{array}$ & $\begin{array}{c}\text { Exposure } \\
(\mathbf{m i n})\end{array}$ & Delay $^{\mathbf{y}}$ & Free & From sori \\
\hline 1.60 & 11.5 & 25 & 5 & 0 & $0.8 \mathrm{~b}$ & $41.4 \mathrm{~b}$ \\
1.60 & 11.5 & 25 & 5 & 10 & $0.0 \mathrm{a}$ & $41.7 \mathrm{~b}$ \\
1.60 & 8.0 & 25 & 5 & 10 & $0.0 \mathrm{a}$ & $19.0 \mathrm{c}$ \\
1.60 & 8.0 & 25 & 15 & 0 & $0.0 \mathrm{a}$ & $10.8 \mathrm{~d}$ \\
Water alone & $\cdots$ & 25 & 5 & 0 & $33.8 \mathrm{c}$ & $69.6 \mathrm{a}$ \\
Water alone & $\cdots$ & 25 & 15 & 0 & $38.5 \mathrm{c}$ & $47.7 \mathrm{~b}$ \\
\hline
\end{tabular}

${ }^{\mathrm{y}}$ Delay in minutes before the seeds were rinsed in fresh water.

${ }^{\mathrm{z}}$ Values followed by different letters are significantly different $(P \leq 0.05)$ according to Duncan's new multiple range test. of seeds and teliospores with $1.60 \%$

$80^{\circ} \mathrm{C}$ for $30 \mathrm{~min}$

with water at $25^{\circ} \mathrm{C}$ was $34.7 \%+5.0 \%$ 1). At 25 and $60^{\circ} \mathrm{C}$, the inhibition of at $1.60 \%$ was significantly $(P=0.02)$ suNaCl at $0.53 \%$. The time to kill 0.53 or $1.60 \%$ hypochlorite was 24.2 and $7.1 \mathrm{~min}$, respectively. The time to kill $99 \%$ of the free teliospores at $60^{\circ} \mathrm{C}$ with 0.53 or 
$1.60 \% \mathrm{NaOCl}$ was 2.7 and $0.2 \mathrm{~min}$, respectively.

Germination of teliospores from within sori treated with water at $25^{\circ} \mathrm{C}$ was $48.3 \%$ $\pm 15.0 \%$ (Table 1). Germination of teliospores from sori was greater than that of free teliospores, probably because when the free teliospores were first prepared by crushing sori, many of the teliospores were cracked. Survival of teliospores within sori was significantly $(P<0.001)$ greater after heat and $\mathrm{NaOCl}$ treatments than that of free teliospores at 25 and $60^{\circ} \mathrm{C}$. At $25^{\circ} \mathrm{C}$, $\mathrm{NaOCl}$ did not kill all teliospores within sori after $30 \mathrm{~min}$ of treatment. Control of teliospores within sori by 0.53 or $1.60 \%$ $\mathrm{NaOCl}$ was not significantly different. No teliospores survived any $80^{\circ} \mathrm{C}$ treatment, with the exception of two teliospores from sori, one of which survived a 5-min treatment in water and the other a 5-min treatment in $0.53 \% \mathrm{NaOCl}$.

Treatment with $1.60 \% \mathrm{NaOCl}$ at $25^{\circ} \mathrm{C}$ for $5 \mathrm{~min}$ followed by a delay of $10 \mathrm{~min}$ before rinsing with fresh water killed free teliospores but not all teliospores within sori (Table 2). This treatment was better than a 5-min treatment alone but significantly inferior to a continuous 15 -min treatment with $1.60 \% \mathrm{NaOCl}$. The efficacy of $\mathrm{NaOCl}$ solutions adjusted to $\mathrm{pH} 8$ before use was significantly superior to that of solutions at $\mathrm{pH} 11.5$, but some teliospores within sori survived.

The color of most of the free teliospores
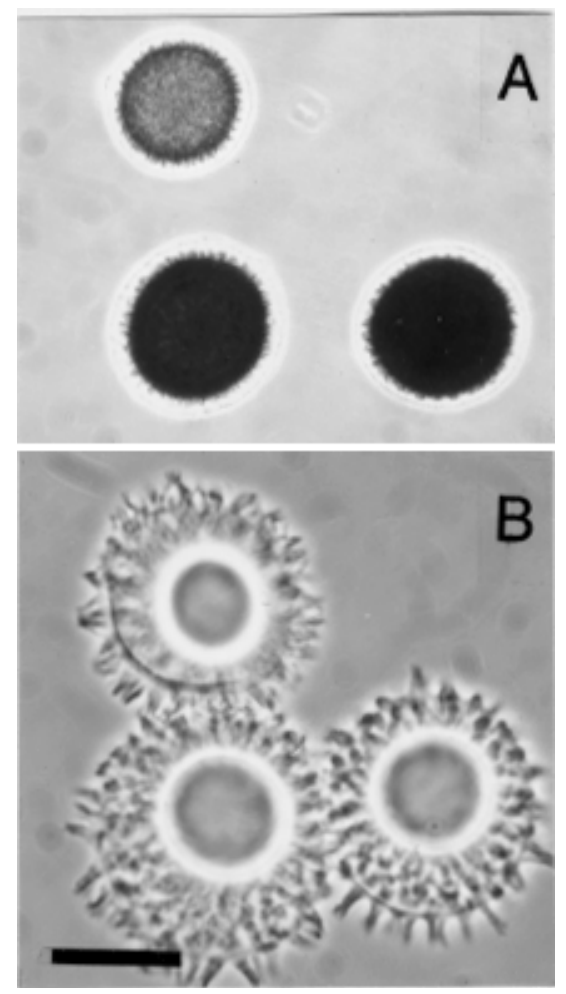

Fig. 1. (A) Untreated teliospores of Tilletia indica and (B) teliospores treated for $30 \mathrm{~min}$ with $1.6 \% \mathrm{NaOCl}$. The brown to dark brown color is absent after treatment, and the teliospore wall becomes enlarged and disorganized. Bar $=30 \mu \mathrm{m}$. and many of the teliospores from within sori was bleached, and the spore wall and sheath were greatly expanded after $\mathrm{NaOCl}$ treatments (Fig. 1). Completely decolorized, expanded teliospores did not germinate, but some partially decolorized teliospores did germinate.

\section{DISCUSSION}

The primary findings of this work are (i) $80^{\circ} \mathrm{C}$ water kills nearly all teliospores of $T$. indica after $1 \mathrm{~min}$ of contact, even if they reside inside unruptured sori at the time of treatment; (ii) the addition of $\mathrm{NaOCl}$ to water kills more free teliospores than hot water alone; and (iii) the altered appearance of teliospores usually leaves a persistent indication that they have been treated with $\mathrm{NaOCl}$. The addition of $\mathrm{NaOCl}$ to hot water adds both confidence that fewer teliospores will survive treatment and a visual indication that they have been treated. Teliospores within sori, however, resisted $\mathrm{NaOCl}$ treatments, were irregularly bleached, and were reliably controlled only at $80^{\circ} \mathrm{C}$. Therefore, we recommend the removal of as many seeds as possible from equipment or facilities to be treated before the treatments are applied. With appropriate worker safety and environmental precautions, a combination of hot water and $\mathrm{NaOCl}$ could be applied by adding $\mathrm{NaOCl}$ to the water heated in steam or hot water cleaners or a $\mathrm{NaOCl}$ solution could be injected into the steam or water stream afterward. The $\mathrm{pH}$ of the $\mathrm{NaOCl}$ solution should be high (about 11.5), because decomposition to chlorine gas will occur if solutions of lower $\mathrm{pH}$ are heated (16). A rinse with fresh water after the treatments are applied is recommended to reduce corrosion damage to equipment and painted surfaces, although lengthening the period between application of the $\mathrm{NaOCl}$ and rinsing will improve the efficacy of the treatment. Treated equipment should be placed on wash-containment mats before treatment so that runoff $\mathrm{NaOCl}$ and rinse water do not contaminate soil.

The heat and $\mathrm{NaOCl}$ treatments we report that killed teliospores of $T$. indica within sori are too harsh for wheat seeds to survive without injury. Teliospores contaminating the surfaces of wheat seeds, however, can be greatly reduced by hot water and $\mathrm{NaOCl}$ at rates that do not injure seeds. For example, water alone at $54^{\circ} \mathrm{C}$ for 20 min killed about $90 \%$ of the teliospores of $T$. indica on seed surfaces without inhibiting germination of wheat cultivar Wanser seeds (11). At ambient temperatures, $1.60 \% \mathrm{NaOCl}$ for 10 min killed about $96 \%$ of teliospores of T. indica on seed surfaces without inhibiting germination of wheat cultivar Wanser seeds (11). Harsher treatments injure wheat seed; Chastain (1) reported that wheat cultivars Daws and Stephens survived 15- or 30-s treatment with $1 \% \mathrm{NaOCl}$ at 55 to $60^{\circ} \mathrm{C}$ without injury, although 60-s treatments reduced seed germination and vigor. Approaches to improving the efficacy of $\mathrm{NaOCl}$ sanitation of seeds have been incompletely investigated. Sauer and Burroughs (8) reported that treatment with ethanol before $\mathrm{NaOCl}$ immersion improved the disinfection of wheat seeds contaminated with several Aspergillus spp.; this approach probably would improve $\mathrm{NaOCl}$ efficacy against teliospores of $T$. indica as well. Adding ethanol to $\mathrm{NaOCl}$ probably would improve its effectiveness. The toxicity of formaldehyde to teliospores of $T$. indica was enhanced by ethanol, and ethanol, particularly at a concentration of $40 \%$, was itself an effective sporicide at ambient temperature (12).

The combination of heat and $\mathrm{NaOCl}$ achieves most of the attributes required of a feasible sanitation treatment: (i) it is effective against free teliospores and teliospores within sori, although every effort to remove infected seeds before treatment should be made; (ii) it is inexpensive and readily available; (iii) worker and environmental hazards can be managed; and (iv) the teliospore appearance is altered, usually leaving a persistent indication that teliospores have been treated so that compliance with treatment orders is evident.

\section{ACKNOWLEDGMENTS}

This study was made possible by financial support provided by the U.S. Department of Agriculture's Animal Plant Health Inspection Service, Plant Protection and Quarantine. We acknowledge the useful suggestions and ideas of S. Wood, J. Moody, A. L. Schipper, R. E. Gingery, and N. W. Schaad. We thank L. McKee, R. C. French, and G. L. Peterson, who contributed to the design and execution of this work, and B. J. Goates for critical review of the manuscript.

\section{LITERATURE CITED}

1. Chastain, T. G. 1991. High-temperature sodium hypochlorite effects on viability of Tilletia controversa teliospores and wheat seed. Crop Sci. 31:1327-1330.

2. Dychdala, G. R. 1991. Chlorine and chlorine compounds. Pages 131-151 in: Disinfection, Sterilization, and Preservation. 4th ed. S. S. Block, ed. Lea and Febiger, Philadelphia.

3. Finney, D. J. 1971. Probit Analysis. 3rd ed. Cambridge University Press, New York.

4. Gill, K. S., Sharma, I., and Aujla, S. S. 1993. Karnal Bunt and Wheat Production. Punjab Agricultural University Press, Ludhiana, India.

5. Joshi, L. M., Singh, D. V., and Srivastava, K. D. 1983. Karnal bunt: A minor disease that is now a threat to wheat. Bot. Rev. 49:309330.

6. Mitra, M. 1935. Studies on the stinking smut or bunt of wheat in India. Indian J. Agric. Sci. 7:459-478.

7. Rai, R. C., and Singh, A. 1979. Effect of chemical seed treatment on seed-borne teliospores of Karnal bunt of wheat. Seed Res. 7:186189.

8. Sauer, D. B., and Burroughs, R. 1986. Disinfection of seed surfaces with sodium hypochlorite. Phytopathology 76:745-749.

9. Singh, A. 1995. Epidemiology and management of Karnal bunt disease of wheat. G. B. Pant Univ. Agric. Technol. (Pantnager, India) Res. Bull. 127.

10. Singh, B. B., Aujla, S. S., and Sharma, I. 
1993. Integrated management of wheat Karnal bunt. Int. J. Pest Manage. 39:431-434.

11. Smilanick, J. L., Goates, B. J., Denis-Arrue, R., Simmons, G. F., Peterson, G. L., and Henson, D. J. 1994. Germinability of Tilletia spp. teliospores after hydrogen peroxide treatment. Plant Dis. 78:861-865.

12. Smilanick, J. L., Hoffmann, J. A., Secrest, L. R., and Wiese, K. 1988. Evaluation of chemical and physical treatments to prevent germination of Tilletia indica teliospores. Plant Dis. 72:46-51.

13. Warham, E. J. 1986. Karnal bunt disease of wheat: A literature review. Trop. Pest Manage. 32:229-242.

14. Warham, E. J., Mujeeb-Kazi, A, and Rosas, V. 1986. Karnal bunt (Tilletia indica) resistance screening of Aegilops species and their practical utilization for Triticum aestivum improvement. Can. J. Plant Pathol. 8:65-70.
15. Warham, E. J., Prescott, J. M., and Griffiths, E. 1989. Effectiveness of chemical seed treatments in controlling Karnal bunt disease of wheat. Plant Dis. 73:585-588.

16. White, G. C. 1992. The Handbook of Chlorination. Van Nostrand Reinhold, New York.

17. Ykema, R. E., Floyd, J. P., Palm, M. E., and Peterson, G. L. 1996. First report of Karnal bunt of wheat in the United States. Plant Dis. 80:1207. 